\title{
Comment on the article: "Prediction of the development of acute kidney injury following cardiac surgery by machine learning"
}

\author{
Hang Zhang ${ }^{1}$, Yang Zhao ${ }^{2}$ and Tongtong Gu 3* $^{*}$
}

\section{To the editor}

We read with great interest the article published in Critical Care by Tseng et al. [1] reporting prediction of cardiac surgery-associated acute kidney injury (CSA-AKI) using machine learning (ML). Using SHapley Additive exPlanation (SHAP) analysis, the authors identified a set of intraoperative features attribute to AKI, highlighting the value of intraoperative data in AKI risk prediction.

Among 94 clinical features, intraoperative urine output (IUO) was identified as the most influential feature, which may reflect acute respond for renal function. However, a majority of patients $(70.2 \%)$ received cardiopulmonary bypass $(\mathrm{CPB})$. In the $\mathrm{CPB}$ setting, usually, IUO does not assure actual renal function as a result of cold diuresis and centrally shunted non-pulsatile blood flow $[2,3]$. More importantly, intraoperative fluid balance was significantly different in patients with or without AKI (9.8 [7.7-12.8] vs. $11.8[8.7-15.6] \mathrm{mL} / \mathrm{kg} / \mathrm{h}, P<0.001)$ and there was a great individual difference among two cohorts. The authors defined AKI based on the changes in postoperative serum creatinine $(\mathrm{Scr})$ levels, while not adjusting the effect of fluid balance may significantly underestimate the incidence of AKI, as a positive perioperative fluid balance may dilute Scr levels [4]. Taken together, the association between IUO and AKI is complex and needs to be further evaluated after adjusting

*Correspondence: gutongtong456@163.com

${ }^{3}$ Department of Clinical Pharmacy, Jinshan Hospital Affiliated To Fudan University, No. 1508 Longhang Road, Shanghai 201508, China

Full list of author information is available at the end of the article potential clinical confounders (e.g., intraoperative fluid infusion, conventional ultrafiltration, body temperature).

Typically, the benefits of ML start to become apparent when the sample size exceeds 5000-10,000. The authors validated the ML models in a relatively few patients cohort (202 patients and 49 AKI cases), with the area under the receiver operating characteristic curves (AUCs) ranging 0.781-0.843. In addition to AUC, more interpretable indicators should be introduced into the evaluation of a ML model such as accuracy, sensitivity, specificity, positive predictive value, negative predictive value, and F1 score, as adequate discrimination (AUC >0.8) may not imply good performance in the sensitivity and positive predictive value of the model. In particular, in the serious clinical condition like CSAAKI, sensitivity is emphasized over specificity [5]. These parameters can be easily obtained from a confusion matrix. Therefore, if the authors were able to calculate them, we believe that the models will be more credible and will present more practical value.

The rapid development of ML techniques will certainly facilitate the management of AKI patients. The authors made an important contribution in explainable ML technology (SHAP values). We look forward to more valuable researches on CSA-AKI using advanced ML algorithms.

\section{Abbreviations}

CSA-AKI: Cardiac surgery-associated acute kidney injury; ML: Machine learning; IUO: Intraoperative urine output; Scr: Serum creatinine; AUC: Area under the receiver operating characteristic curve.

Acknowledgements

None.

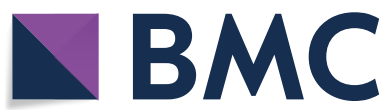

(c) The Author(s) 2021. Open Access This article is licensed under a Creative Commons Attribution 4.0 International License, which permits use, sharing, adaptation, distribution and reproduction in any medium or format, as long as you give appropriate credit to the original author(s) and the source, provide a link to the Creative Commons licence, and indicate if changes were made. The images or other third party material in this article are included in the article's Creative Commons licence, unless indicated otherwise in a credit line to the material. If material is not included in the article's Creative Commons licence and your intended use is not permitted by statutory regulation or exceeds the permitted use, you will need to obtain permission directly from the copyright holder. To view a copy of this licence, visit http://creativecommons.org/licenses/by/4.0/. The Creative Commons Public Domain Dedication waiver (http://creativecommons.org/publicdomain/zero/1.0/) applies to the data made available in this article, unless otherwise stated in a credit line to the data. 


\section{Authors' contributions}

$H Z, Y Z$, and TTG drafted the letter. All authors read and approved the final version.

\section{Funding}

None.

\section{Availability of data and materials}

Not applicable.

\section{Declarations}

Ethics approval and consent to participate

Not applicable.

\section{Consent for publication}

Not applicable.

\section{Competing interests}

The authors declare that they have no competing interests.

\section{Author details}

'Department of Thoracic and Cardiovascular Surgery, Nanjing First Hospital, Nanjing Medical University, No. 68 Changle Road, Nanjing 210006, China.

${ }^{2}$ Department of Biostatistics, School of Public Health, Nanjing Medical University, No. 101 Longmian avenue, Nanjing 211166, China. ${ }^{3}$ Department of Clinical Pharmacy, Jinshan Hospital Affiliated To Fudan University, No. 1508 Longhang Road, Shanghai 201508, China.
Received: 15 October 2021 Accepted: 18 October 2021

Published online: 26 October 2021

\section{References}

1. Tseng PY, Chen YT, Wang CH, Chiu KM, Peng YS, Hsu SP, Chen KL, Yang CY, Lee OK. Prediction of the development of acute kidney injury following cardiac surgery by machine learning. Crit Care. 2020;24(1):478.

2. Lannemyr L, Bragadottir G, Krumbholz V, Redfors B, Sellgren J, Ricksten SE. Effects of cardiopulmonary bypass on renal perfusion, filtration, and oxygenation in patients undergoing cardiac surgery. Anesthesiology. 2017;126(2):205-13.

3. Mongero L, Stammers A, Tesdahl E, Stasko A, Weinstein S. The effect of ultrafiltration on end-cardiopulmonary bypass hematocrit during cardiac surgery. Perfusion. 2018;33(5):367-74.

4. Moore E, Tobin A, Reid D, Santamaria J, Paul E, Bellomo R. The impact of fluid balance on the detection, classification and outcome of acute kidney injury after cardiac surgery. J Cardiothorac Vasc Anesth. 2015;29(5):1229-35.

5. Liu X. Classification accuracy and cut point selection. Stat Med. 2012;31(23):2676-86.

\section{Publisher's Note}

Springer Nature remains neutral with regard to jurisdictional claims in published maps and institutional affiliations.
Ready to submit your research? Choose BMC and benefit from:

- fast, convenient online submission

- thorough peer review by experienced researchers in your field

- rapid publication on acceptance

- support for research data, including large and complex data types

- gold Open Access which fosters wider collaboration and increased citations

- maximum visibility for your research: over 100M website views per year

At BMC, research is always in progress.

Learn more biomedcentral.com/submissions 